Article

\title{
The Role of Managerial Skills in the Sustainable Development of SMEs in Mehedinti County, Romania
}

\author{
Luminita Popescu 1,*(D), Anica Iancu ${ }^{1}$, Marioara Avram ${ }^{2}$, Daniel Avram ${ }^{2}$ and Virgil Popescu ${ }^{3}$ \\ 1 Department of Management, Marketing and Business Administration, University of Craiova, Al. I. Cuza, \\ No. 13, 200585 Craiova, Romania; iancu.nina@ucv.ro \\ 2 Department of Economics, Accounting and International Business, University of Craiova, Al. I. Cuza, No. 13, \\ 200585 Craiova, Romania; avram.marioara@ucv.ro (M.A.); avram.daniel@ucv.ro (D.A.) \\ 3 Department of Statistics and Economic Informatics, University of Craiova, Al. I. Cuza, No. 13, \\ 200585 Craiova, Romania; virgil.popescu@expert.org.ro \\ * Correspondence: luminita.popescu@expert.org.ro
}

Received: 26 December 2019; Accepted: 24 January 2020; Published: 4 February 2020

check for updates

\begin{abstract}
The ever-changing external environment and the challenges and signals transmitted by the European Single Market have greatly contributed to the dynamism of SMEs in Europe. From the privileged place held by the entrepreneur in SMEs, the present study aims to investigate the role of managerial skills in the sustainable development of small and medium enterprises, focused on self-awareness, emotional intelligence, and interpersonal skills of entrepreneurs. The investigation method consisted of the distribution of anonymous questionnaires to a representative sample of entrepreneurs, in the Mehedinți County, Romania. The collected data were centralized, processed, and assessed. The results of this analysis revealed, besides the emotional intelligence and interpersonal skills which have reached a suitable level, a low level of self-awareness. Therefore, this has been considered as a potential barrier towards sustainable development of SMEs in the analyzed region. However, the high level of emotional intelligence, accompanied by an increasing trend of interpersonal skills as the manager's experience in working with people increases, is a strong argument for the sustainable development of SMEs. The study comes to support the public policies concerning small and medium-sized entities by using a model of managerial skills testing for applicants. In this way, an increase of the transparency of financing decision and the effectiveness of financial support are ensured.
\end{abstract}

Keywords: sustainable development; SMEs density; managerial skills; self-awareness; emotional intelligence; interpersonal skills

\section{Introduction}

Mehedinti County, territorial administrative unit (NUTS 3 - Nomenclature of Territorial Units for Statistics) located in the South-West Oltenia Euroregion (NUTS 2), had registered in 2017 a density of 12.9 small and medium-sized enterprises (SMEs) per thousand inhabitants, the lowest level within the Euroregion, which, in turn, registered an average of 18.7 SMEs per thousand inhabitants. SMEs are viewed as important contributors to the global economy, and are big employment generators [1]. In 2017, Romania registered overall an average of 29 SMEs per thousand inhabitants in the non-financial business sector, while in the European Union (EU), two-thirds of all jobs are provided by SMEs, and the average number of SMEs per thousand inhabitants was 57 . Over $80 \%$ of employees work in SMEs in many European countries [2,3]. The low level of SMEs in the Mehedinti County is influenced by other indicators such as the average income, which is below the national average, the reduced level of foreign investments, and a high level of unemployment. 
Under these circumstances, the study aims to analyze the possibilities to improve the sustainability of SMEs in terms of managerial skills of the entrepreneurs. This aspect is also mentioned in the Annual Report of SMEs 2016-2017, where the availability of skilled staff or experienced managers is ranked as the second pressing issue faced by SMEs in 2017 [4].

For SMEs the management process requires versatile technical, economic, and behavioral knowledge, and that the information system is simple and direct, but the managerial skills are the ones that make the difference between a successful enterprise and one that has failed.

The importance of managerial skills in emerging economies is emphasized in the literature, suggesting that managerial skills play a key role in the adoption and implementation of new and modern technologies, especially in developing countries. According to Beaudry and Francois, there is no incentive for knowledgeable managers from developed countries (where managerial knowledge is abundant) to migrate to a less developed country (where it is scarce). This finding gives a possible explanation about the persistence of under-development, suggesting that experienced managers will not migrate from richer to poorer countries due to the level of wages and their teaching value [5].

This article proposes an analysis of the managerial skills that influence the sustainable development of SMEs, structured on three levels:

- Self-awareness,

- emotional intelligence,

- interpersonal skills.

Therefore, a set of anonymous questionnaires was distributed and processed, applied on a representative sample of the investigated population, respectively persons who have effectively set up and run SMEs in Mehedinți County. The results obtained could be useful to identify ways for improving the managerial skills, which is a prerequisite for the sustainable development of SMEs.

\section{Literature Review on Managerial Skills}

SMEs represent in fact a major component of any economy nowadays. The dynamics of setting up new businesses follow an upward trend, since more and more people want to be their own master, have a higher standard of living, and use their creativity to carry out activities based on their own passions and talents. Some entrepreneurs successfully manage to transform their ideas into profitable businesses and to develop them further, while others, though making sustained efforts, fail to reach the level of competitiveness desired, and poor results sometimes even lead them to giving up the business.

Small and medium-sized enterprises attract a lot of attention in terms of policy development and implementation, and because they are considered to be the backbone of both developed and developing economies, they represent key drivers for economic growth, innovation, employment, and social integration. Moreover, SMEs develop healthier employee relations than larger organizations and possess more devoted and committed employees [6], and may be more able to sustain their employment levels and thus counteract helping to stabilize and develop the economy [7].

In addition to the ever-changing external environment in which SMEs operate, a significant influence on their performance is given by the entrepreneur. He decisively influences the performance of his own business through the level of his knowledge, skills, abilities, and attitude.

Successful business depends largely on the level of knowledge and experience of the entrepreneurs, but their managerial skills are just as important.

Over time, there have been many concerns about identifying the managerial skills that contribute to the development of successful organizations. Answers to various questions such as: How can you be a good manager? What are the differences between efficient and less efficient entrepreneurs/managers? How and how much do managerial skills influence the success of the organization? How can managerial skills be developed? These are still important topics for management specialists, but also for management practitioners. 
Managers have the fundamental duty to mobilize and motivate people to achieve collective goals by defining and communicating tasks, organizing the employees according to their tasks, and providing them an appropriate working environment [8]. Therefore, a set of individual characteristics specific to managers is needed to influence the achievement of desired performance [9].

Regardless of the type of organization they lead and their hierarchical level, managers must have specific managerial skills, which influence decisively their level of performance and the achievements of their team. Skill stands for the ability, aptitude, deftness, prowess, or competence to perform certain tasks or activities [10].

In other words, managerial skills can be defined as [11]:

- A set of characteristics that help individuals to achieve better results and to be successful;

- characteristics needed to carry out the managerial processes necessary to obtain efficient results in the organization;

- $\quad$ basic features for managerial efficiency;

- characteristic attitudes of managers by means of which they manage to impose their own style, strategies, techniques, and tools in the organization.

According to Simionescu, in order to successfully fulfill their tasks, managers need four basic types of skills: Professional, interpersonal, conceptual, analysis and diagnosis skills [12]:

- Professional (specialized) skills consist of the knowledge necessary for their field of activity (lawyers, economists, teachers, engineers, etc.) and are acquired by attending formal education.

- Interpersonal skills mean the ability to work with people, to communicate with groups or individuals and understand them.

- Conceptual skills depend on the managers' ability of abstracting; they allow them to analyze the organization as a whole, understand the cause-effect relationships in the organization, and think strategically.

- Analysis and diagnosis skills refers to the manager's ability to identify the most appropriate response to a given situation. These skills help defining the problem and discovering possible causes, analyzing the options of response, choosing the optimal variant, implementing the solution, and monitoring the results.

Starting from the idea that a skill implies one competence that can be developed further on, Katz [13] suggests that the efficient management of an organization is based on three fundamental skills needed by managers:

- A set of characteristics that help individuals to achieve better results and to be successful;

- characteristics needed to carry out the managerial processes necessary to obtain efficient results in the organization;

- basic features for managerial efficiency;

- characteristic attitudes of managers by means of which they manage to impose their own style, strategies, techniques, and tools in the organization.

According to Simionescu, in order to successfully fulfill their tasks, managers need four basic types of skills: Professional, interpersonal, conceptual, analysis and diagnosis skills [12]:

- Professional (specialized) skills consist of the knowledge necessary for their field of activity (lawyers, economists, teachers, engineers, etc.) and are acquired by attending formal education.

- Interpersonal skills mean the ability to work with people, to communicate with groups or individuals and understand them.

- Conceptual skills depend on the managers' ability of abstracting; they allow them to analyze the organization as a whole, understand the cause-effect relationships in the organization, and think strategically. 
- Analysis and diagnosis skills refers to the manager's ability to identify the most appropriate response to a given situation. These skills help defining the problem and discovering possible causes, analyzing the options of response, choosing the optimal variant, implementing the solution, and monitoring the results.

Starting from the idea that a skill implies one competence that can be developed further on, Katz suggests that the efficient management of an organization is based on three fundamental skills needed by managers [13]:

- Technical abilities, which involve understanding and competence in a particular type of activity, especially one based on methods, processes, procedures, or techniques. These skills are the most well-known and concrete, so most of the professional training programs are basically concerned with the development of specialized technical skills.

- Skills in the field of human relations, which refer to the abilities of managers to establish and maintain good contacts with subordinates, superiors, other managers, even with people outside the organization. By accepting point of views, perceptions, and beliefs different from their own, managers create an atmosphere of approval and security in which subordinates feel free to express opinions without fear of censorship or ridicule, thus encouraging them to participate in planning and performing the organization's activities. Developing these abilities allows managers to correctly identify and be sensitive to the needs and motivations of employees so they can avoid potential negative reactions of personnel to their actions and can determine its full involvement in meeting the organization's goals.

- Conceptual abilities, which refer to the ability of managers to perceive the whole organization. These skills allow recognition of how the different functions of an organization are interdependent, but also visualization of the organization's relationship with the industry, the community to which it belongs, and the economy's political, social, and economic forces overall.

Recent approaches to the set of characteristics required by organizational leaders separate managerial skills into three broad categories [14]:

- Personal skills (knowledge and self-development, management of time and stress, identifying, defining, and solving any problems creatively).

- Interpersonal skills (conflict management, motivating and influencing employees, supportive communication, gaining power and influence).

- Group skills (creating effective teams, implementing positive changes, empowering employees, and delegating tasks).

According to Pfeffer [15], managerial and organizational effectiveness is based on seven key practices: Ensuring job security, selective employment of people, encouraging decentralization and self-management of teams, implementing a high performance-based payroll, extensive training, reducing status differences, and exchanging information. In 2000, Brodbeck et al. conducted a study in 22 countries across Europe on 6052 middle-level managers, mainly focused on testing the hypothesis according to which the leadership concepts vary depending on cultural differences, and on determining the dimensions that describe the differences in leadership concepts in these countries [16]. Thus, the aptitudes that differentiate managers are inspiration, spirit of self-sacrifice, diplomatic tact, integrity, self-centeredness, self-awareness, self-criticism, modesty, autonomy, visionary spirit, and administration capacity.

Concerns about identifying the managerial skills needed by efficient and performing organizations are welcome, but there are also important concerns about how they can be developed throughout life.

A model for development of managerial skills is presented in Figure 1: 


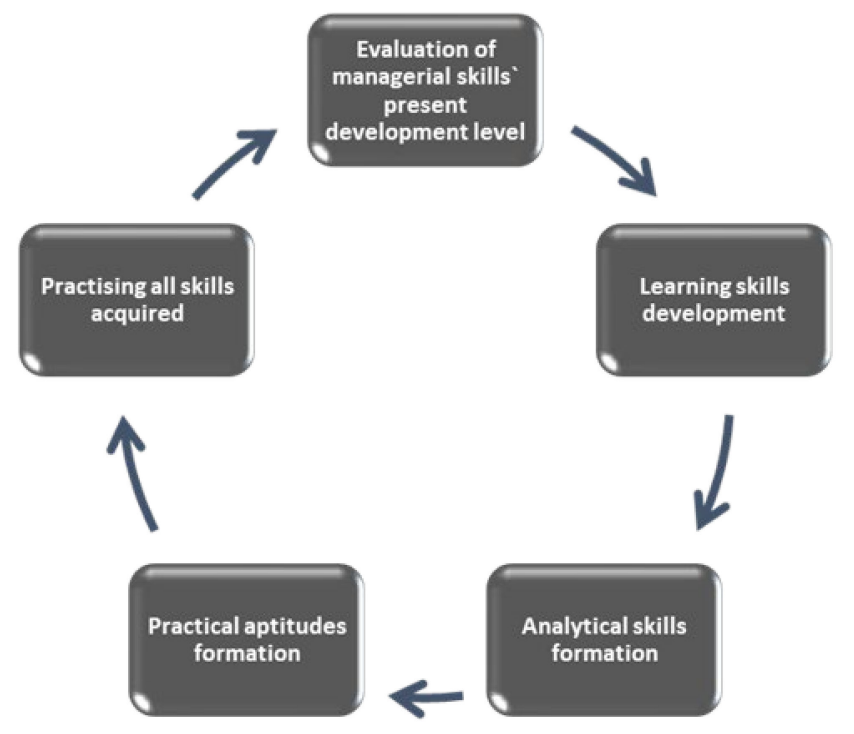

Figure 1. Development of managerial and leadership skills: Learning Model [14].

The profession of manager is very complex, and the expectations from those who hold these positions are also very high, so the continuous improvement of all the individual characteristics that meet these expectations is an essential condition for an efficient manager, which also influences the sustainable development of SMEs.

Developing competent managerial skills is much more complicated than developing other skills because they are based on more complex knowledge than other types of skills and, furthermore, they depend on interaction with other persons.

On the other hand, what all the skills have in common is the potential for improvement through practice. Any approach to the development of managerial skills must therefore involve a strong dose of practical application. At the same time, practice without the necessary conceptual knowledge is sterile and ignores the need for flexibility and adaptability to different situations. Therefore, the transformation of theoretical competences in management skills is inherently related to both conceptual learning and behavioral practice [14].

In Romania, the existing trends in entrepreneurial success have been analyzed in a survey conducted by Rasca (cited by Roseti in 2018) in 2006 and 2016, based on questionnaires and interviews, applied to representative samples of entrepreneurs with one or more businesses, which had over five years of seniority [17]. Though the respondents considered in 2006 that the most important factors of their success were effective management (93.3\%), the desire to achieve personal aspirations and objectives (87.3\%), and the ability to take calculated risks (83.4\%), at the level of 2016, the percentage of those who considered calculated risks the most important lowered to $73.3 \%$, while the percentages related to the other factors increased $(97 \%, 88.7 \%$, respectively), one of the causes being the maturity reached by the entrepreneurs.

Analysis of the 2016 questionnaire responses showed that the main skills that helped them overcome difficulties, develop their businesses, and have a competitive advantage were, in order of frequency, the ability to identify and exploit the right opportunities, the capacity to be visionary and to influence the others, the possibility to be able to control themselves in uncertain situations, and the ability to develop relationships based on mutual trust.

A research direction, addressed by numerous studies, has identified an important obstacle to the sustainable development of SMEs, namely the inadequacy of managerial skills and abilities, that can occur either when they exceed or, on the contrary, when they do not rise to the level of the expectations. If, at first, it was thought to be an isolated, random phenomenon [18], the idea crystallized over time that in fact the inadequacy of managerial skills is highlighted by the mismatch of "individuals' preferences, interests, needs, skills, demographic characteristics and required qualifications, physical 
and mental demands, stability, compensation, benefits, and locations of the jobs they do." [19]. Skills inadequacy may occur as a result of inadequate qualifications, skills inadequacy, or inappropriate field of study, or the combination of all these elements [20].

Under the impact of technological development and the explosion of information, there is a strong polarization of human resources that generates inadequacy both by over-competence and the backwardness in a dynamic environment. Thus, there have been studies published that talk about over educated people in the labor market [21-23] or "war for talent" [24], pp.1 as well as the manners in which organizations, managers, and employees can capitalize on the increased competitiveness gained through higher competition.

The speed with which information and knowledge flow, and the degree of product and technology renewal can favor the occurrence of inadequate skills at the workplace, an aspect described in a number of empirical studies [25-29], which have highlighted the effects of skills inadequacy on job satisfaction, wages, and the labor market in general. The speed with which changes occur can lead to the moral wear and tear of the skills required that are altered by the new technologies and need a match between the job requirements and the skills' update [30] so that SMEs can cope with technological and organizational changes. [31]. The professional development of employees and the improvement of their skills can be achieved by means of a system of incentives granted to the employees to increase their professional potential [32]. Consequently, numerous studies have been devoted to issues related to increasing the competitiveness of SMEs in the global economy [33], policies and strategies for increasing performance [34], corporate sustainability [35], or sustainable reporting integrated into management control systems [36], starting from the premise that a growth of the inadequacy of managerial skills and competences of the employees can "affect implementation of sustainable human resource management" [37].

Sustainable leadership [38] requires special attention for the promotion of long-term sustainable value and the involvement of all stakeholders to keep up with the challenges of scientific and technological progress.

\section{Research Methodology}

A study performed by Katz [13] introduced the three-skill approach (technical skills, human skills, and conceptual skills) as being an essential set of traits for a successful manager. Starting from Katz' pattern, the present study was focused on the human skills, i.e., self-awareness, emotional intelligence, and interpersonal skills. This is the first stage of a more complex research work, which will be developed later, on including the technical skills and conceptual skills. Based on this hypothesis, a quantitative descriptive analysis has been performed to assess the influence of these traits on the sustainable development of SMEs in the Mehedinti County.

To study the level of development of managerial skills in SMEs from Mehedinți County, Romania, an empirical study was performed using the survey as a quantitative research method starting from the hypothesis, validated by the scientific literature presented above, according to which managerial skills within their generally valid framework, for all entities that are considered SMEs, are characterized by:

- Self-awareness development level,

- emotional intelligence,

- $\quad$ interpersonal skills level.

Answers to questionnaires were collected from a total of 362 participants. The study has been conducted on a period between September 2017 to March 2018, covering the SMEs from Mehedinti County. The entrepreneurs participating in the survey have been selected trying to cover most of the economic activities in the Mehedinti County, both rural and urban area, gender equality, age, level of studies, and the willingness to participate in the survey. 


\subsection{Description of Research Instrument}

First of the issues investigated relates to self-awareness, which can be considered an advantage of the human species compared to other life forms existing on the planet.

Entrepreneurs initiate a business with the primary purpose of obtaining a source of income, but, along the way, this activity becomes a way of evolution, self-awareness, and positive influence on the world in which we live. Gruianu and Gambra [39] believe that those entrepreneurs who succeed in maintaining the dynamic balance between managing their business and conducting their lives in a harmonious way undergo an accelerated process of self-development. Thus, one can speak of self-awareness, in the case of entrepreneurs who:

- Harbor intentions, thoughts, and actions that are beneficial to all those involved in the company's activity;

- consider health and wellness very important (included in the list of business priorities);

- show integrity in all situations;

- live their life at the present moment.

The second aspect investigated influencing business management is emotional intelligence.

In "Working with Emotional Intelligence", Daniel Goleman [40], one of the pioneers of research in this field, shows that emotional intelligence (EQ) accounts for about $67 \%$ of the skills and competences needed for a leader to deliver superior performance, and those skills matter twice as much as the technical expertise (regarding a job's main activity) and IQ (the intelligence coefficient).

The importance of EQ development is indisputable for all people, but researches show that the emotional state of a leader is contagious for the team and organization he is part of [41].

Genetic heritage endows each person with a series of emotions that will determine the behavior, all these emotions actually impulses that determine the action, the actual transition to deeds [42].

Self-awareness and emotional intelligence are only a part of the skills that an entrepreneur needs for the development of his business, usually the part that is not visible among the other visible assets, such as knowledge and skills. This approach to managerial skills is based on the competency iceberg model [38] where one-ninth of the iceberg is above the water containing the so-called visible features. The rest of the iceberg, i.e., eight-ninths, is under the water, consisting of the so-called invisible attributes such as: Values, self-image, traits, and motivation.

This paper is focused on the human behavior factor influencing the sustainability of SMEs, among other factors of influence. In an analogy with the competency iceberg model, Figure 2, the self-awareness, emotional intelligence, and interpersonal skills were placed among the not visible features (the part under the water of the iceberg), but are no less important, which significantly influences the attitude, Figure 2.

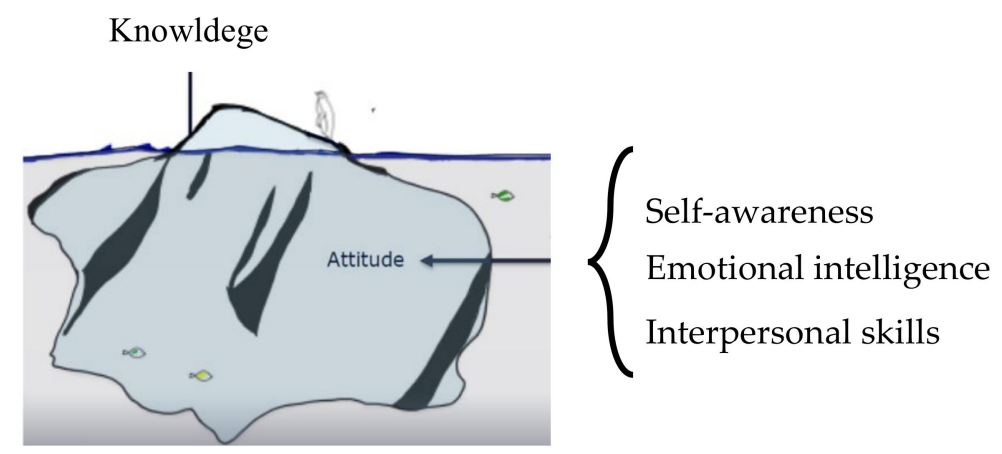

Figure 2. Managerial skills iceberg model.

Performing a scientific research that involves calculating the volume of a representative sample requires a substantial amount of time, energy, and, of course, financial resources. Such studies 
follow several stages, and committing errors, especially at the beginning of the research, can have negative consequences on the results. Therefore, the methodology offers the possibility to use in the research different formulas for calculation of the representative sample, considering their advantages and downsides.

The representativeness criteria are the minimum value of significance test coefficient $t$ and the maximum admitted error $\Delta[43,44]$. This study provides researchers with a figure of 384 statistical units surveyed for statistical collectives larger than 100,000 units or when the volume of statistical collective is unknown. In scientific studies, the maximum accepted value of $\Delta$ (i.e., the relative number of unrepresentative values) is $5 \%$, which for a sample with more than 120 statistical units corresponds to a coefficient $t=1,96$. If we note the volume of the representative sample (n), the number of subjects in the statistical selection base $(N)$, the phenomenon's probability of incidence $(\mathrm{p})$, the phenomenon's lack of probability $(q=1-p)$, the significance test coefficient $(t)$, and the maximum admitted error $(\Delta)$, we can use the relationship (1) [45]:

$$
n=\left[t^{2} \times p(1-p) \times N\right] /\left[t^{2} \times p(1-p) \times N+\Delta^{2} \times N\right]
$$

For the study to which we refer in this article, we have a selection base with the volume $\mathrm{N}=3255$ statistical units (total SMEs in Mehedinţi County in 2016), $\mathrm{t}=1,96, \Delta=5 \%, \mathrm{p}=0.5$, so we find $\mathrm{n}=$ 362.341 , so we choose the value of representative sample $n=362$.

\subsection{Data Collection for the Intended Study}

The questionnaire used to assess self-awareness included a set of 13 questions, with 6 response variants, each scored with $0-5$ points. Self-awareness exists and is manifested when the score is greater than 53 [11].

To assess the level of emotional intelligence, a test consisting of a set of 12 statements, with 5 response variants ranging from 0 to 4 , has been used. Interpretation of the results considers that a total score higher than 36 indicates a suitable level of higher emotional intelligence, between 25 and 34 the level is considered as being good, and the scores below 24 show the need to improve the level of EQ [11].

The interpersonal skills' level of development was investigated using a questionnaire by which several interpersonal skills were evaluated on a scale from 1 (disagreement) to 5 (agreement): Effective listening skills; acceptance of responsibility; the ability to solve problems; adequate expression of feelings and opinions; taking others; recognizing the achievements of others; trust and integrity; an open mind to feedback; accepting the different points of view; alignment of objectives; conflict management.

It is considered that an action plan should be developed to improve these skills when the overall score is less than 60 [11].

\section{Results and Discussion}

Of the 362 people in the representative sample, 216 were men (59.67\%) and 146 (40.33\%) women. The analysis covered all age categories as follows:

- $\quad 20-30$ years, 58 people $(16.02 \%)$;

- $31-40$ years, 114 people $(31.49 \%)$;

- $\quad 41-50$ years, 118 people (32.6\%);

- $\quad$ older than 50,72 people $(19.89 \%)$.

It is noteworthy that entrepreneurship is an activity more prevalent among people aged between 30 and 50 years, whereas for those aged less than 30 years and older than 50 , the percentage is considerably lower (reduced to almost half for the very young ones)—see Table 1. 
Table 1. Centralization of the results.

\begin{tabular}{|c|c|c|c|c|c|c|c|c|c|}
\hline \multirow{2}{*}{ Heading } & \multicolumn{2}{|c|}{ Self-Awareness } & \multicolumn{3}{|c|}{ Emotional Intelligence } & \multicolumn{4}{|c|}{ Interpersonal Skills } \\
\hline & Yes & No & Higher Level & Good Level & Low Level & Excellent & Good & Low & Lowest \\
\hline Number of entrepreneurs & 87 & 275 & 116 & 198 & 48 & 151 & 105 & 75 & 31 \\
\hline Men & 45 & 170 & 65 & 119 & 31 & 92 & 55 & 44 & 24 \\
\hline $20-30 \mathrm{y}$. & 23 & 35 & 24 & 23 & 11 & 21 & 20 & 9 & 8 \\
\hline $31-40 \mathrm{y}$. & 28 & 86 & 36 & 56 & 22 & 44 & 28 & 29 & 13 \\
\hline $41-50 \mathrm{y}$. & 24 & 94 & 30 & 80 & 8 & 57 & 30 & 26 & 5 \\
\hline
\end{tabular}

\subsection{Self-Awareness}

For the analyzed region, only about a quarter of entrepreneurs show self-awareness, while the rest show a low level of self-monitoring. The high levels of self-awareness are related to personal development, healthy relationships, and effective leadership of organizations.

According to Badal and Streur [46], self-awareness-a conscious knowledge of one's own character, feelings, motives, and desires-greatly contributes to the success of a business. In most cases, entrepreneurs focus more on technical and business management skills, ignoring or attaching little importance to the reasons why it is important to develop good self-awareness. Thus, Raphekwane [47] considers that entrepreneurs should focus on self-awareness because:

- Any business depends on the entrepreneur.

- A good understanding of his personal strengths and weaknesses will help capitalize on the key strengths needed to develop the business.

Self-aware entrepreneurs have the ability to accurately perceive others and help them understand their strengths;

- entrepreneurs know how to capitalize on their inner strength;

- self-awareness allows the development of a genuine personal brand;

- decisions are improved by better understanding one's self.

The results obtained show that women entrepreneurs register a higher level of self-awareness (28.57\%) than male entrepreneurs (20.83\%), which is in accordance with another study performed by Schneider et al., revealing that the majority of the women entrepreneurs from Germany and Ireland presented an advanced level of self-awareness [48]

The situation on age groups is presented in Table 2.

Table 2. Self-awareness by age groups.

\begin{tabular}{ccc}
\hline \multirow{2}{*}{ Age } & \multicolumn{2}{c}{ Self-Awareness } \\
\cline { 2 - 3 } & Yes (\%) & No (\%) \\
\hline $20-30$ y. & 39.6 & 60.34 \\
$31-40$ y. & 24.56 & 75.44 \\
$41-51$ y. & 20.34 & 79.66 \\
$>50$ y. & 19.44 & 80.56 \\
\hline
\end{tabular}

Therefore, young entrepreneurs have the highest level of self-awareness, which is considered normal, given that young people nowadays start their entrepreneurial education earlier than older generations.

Another possible explanation for this is that this category of people, known as the Y generation or the Millennials, differs considerably from previous generations and has other values. According to sociologists, the Millennials have confidence in their own strengths, are at ease in accepting opportunities and challenges, believe education is an important factor of success, appreciate teamwork, 
and are more open and tolerant towards minorities, and last but not least, they stay connected to new technologies (being digital natives) and are able to develop their communication skills both in real life and in virtual environment. They also have a developed entrepreneurial spirit and are more willing to start up a business and take risks than the previous generation, the $\mathrm{X}$ generation.

On the other hand, Romanian entrepreneurs who fall under the categories over 40 years have a lower level of self-awareness. They all have the common feature that they were born and educated in the communist era. This generation, as stated by Dancu [49], "has matured socially in troubled times, and its most significant limit is that it has not developed collaboration strategies, but rather competition strategies. Those in Generation X have tried to adapt to the new society, without seeking solidarity of generation, but more through competitiveness, individualism or struggle for survival."

Although not much has been written about self-awareness in the context of entrepreneurial career development in the specialized literature, McCarthy and Garavan [50] have conducted a qualitative study showing that one of the characteristics of professional career development is the creation of self-awareness by using the 360 degree feedback and personality tests (Myers-Briggs Type Indicator-MBTI).

A study of Mckenna that investigates the role of the entrepreneurial personality reveals that self-awareness is the answer to problems in the fast-growing small business [51].

\subsection{Emotional Intelligence}

In terms of emotional intelligence, specialized literature suggests that it plays a significant role in achievement of success at work, but most researches on this topic have an empirical character.

At the level of the area investigated in this study, the results show that most entrepreneurs have registered good and very good levels of emotional intelligence - Figure 3.

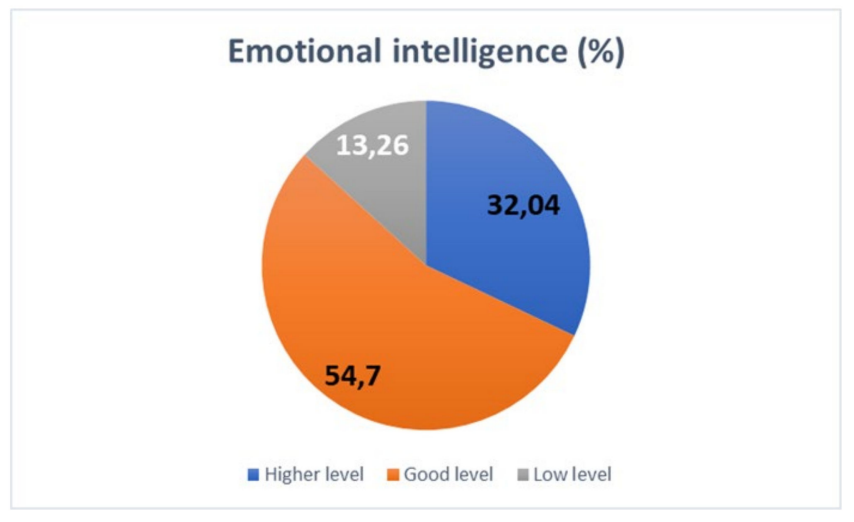

Figure 3. Emotional intelligence of entrepreneurs in Mehedinţi County.

There is no significant difference between the two sexes - Table 3, but the analysis on age category, Figure 4 shows that the percentage of those with a low level of emotional intelligence is higher for young people (under 40), and entrepreneurs aged over 40 register good and excellent levels in a higher percentage.

Table 3. Emotional intelligence values on gender.

\begin{tabular}{cccc}
\hline & \multicolumn{3}{c}{ Emotional Intelligence } \\
\cline { 2 - 4 } & Higher Level (\%) & Good Level (\%) & Low Level (\%) \\
\hline Men & 30.23 & 55.35 & 14.42 \\
Women & 34.01 & 54.42 & 11.57 \\
\hline
\end{tabular}




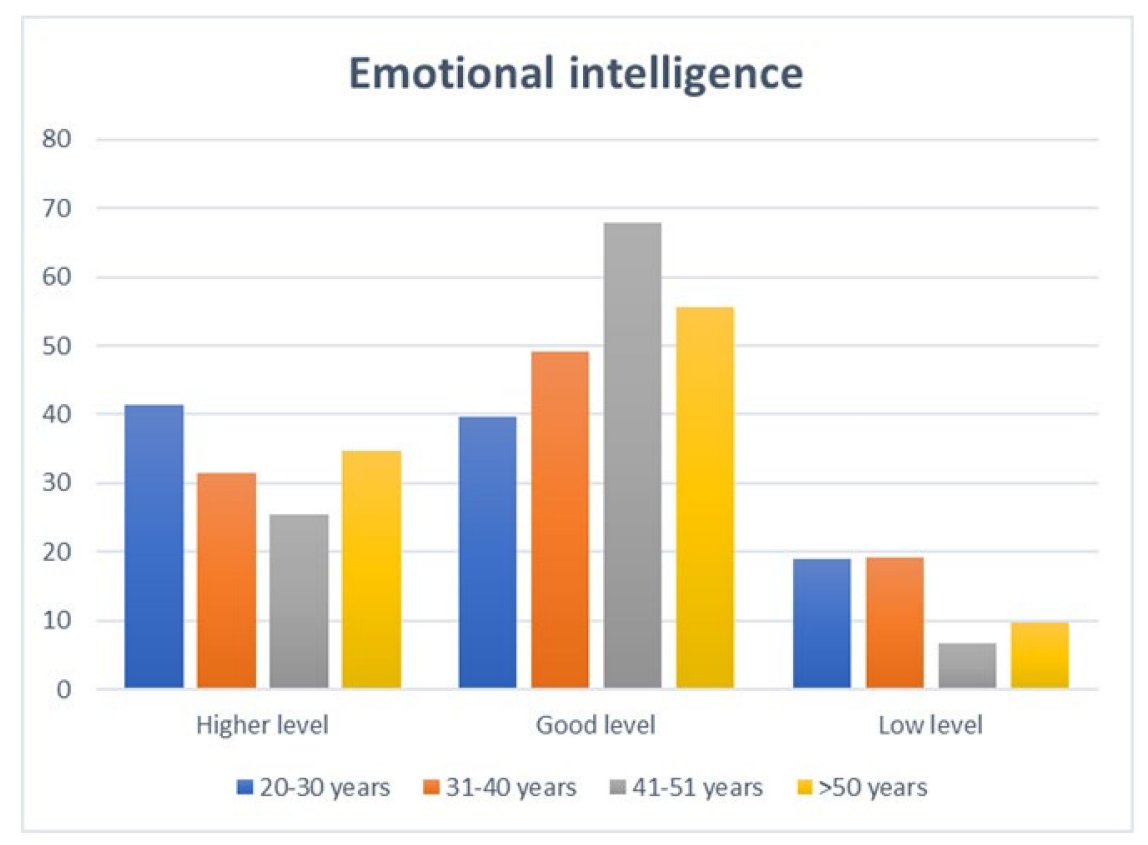

Figure 4. Emotional intelligence levels by age category.

The results of this study confirm that more than $50 \%$ of the entrepreneurs questioned presented a high level of emotional intelligence.

In a study published by Carmeli [52], the results of an empirical research show that high emotional intelligence influences the attitude towards work and performance of senior managers hired as chief financial officers in the local government authorities in Israel.

Another analysis on the connection between effective leadership and emotional intelligence belongs to Gardner and Stough [53]. Thus, they conducted a survey among 110 senior level managers with an average age of 42.7 years, concluding that effective leaders are those who have a transformational, rather than transactional, behavior, and the ability to identify and understand other persons' emotions at the workplace is very important for a leader because he can influence the subordinates' feelings while maintaining their enthusiasm and productivity.

A study presented by Fakhreldin and Hattab, investigating the effect of emotional intelligence of Egyptian entrepreneurs on entrepreneurial behavior and on new venture creation shows that there is a significant relationship between emotional intelligence and entrepreneurial behavior [54].

Another study [55], which covered the influence of the emotional intelligence on the performance of entrepreneurial skills, revealed that emotional intelligence has a partial influence on the entrepreneurial outcomes among other variables.

\subsection{Interpersonal Skills}

Interpretation of the results obtained, Table 1, shows that the level of interpersonal skills development for entrepreneurs in Mehedinti county is either excellent or good, Figure 5, for about $70 \%$ of the respondents.

From the gender analysis, the results show that the number of female entrepreneurs who have good and excellent interpersonal skills levels is slightly higher than that of male entrepreneurs $(74.82 \%$ vs. $68.39 \%)$.

On age category, the best levels of interpersonal skills needed for business development are recorded by entrepreneurs aged over 50 , followed by the $41-0$ years group, then $20-30$ years category, and in last place being situated those with ages between 31 and 40 years - Figure 6. 


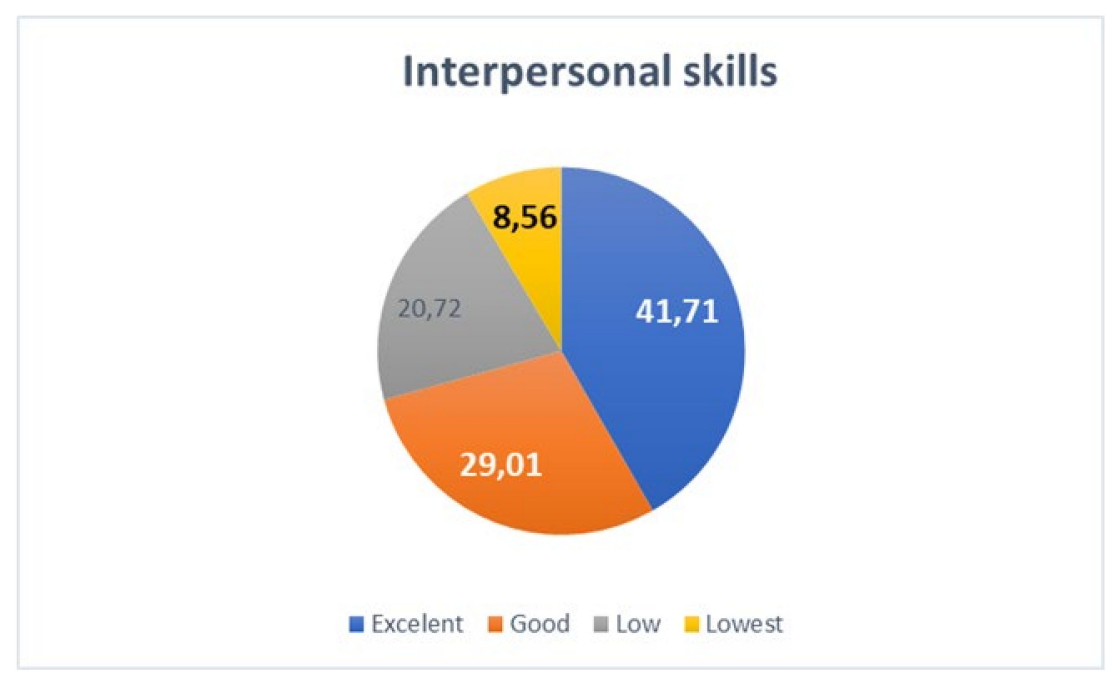

Figure 5. Interpersonal skills of entrepreneurs in Mehedinti County.

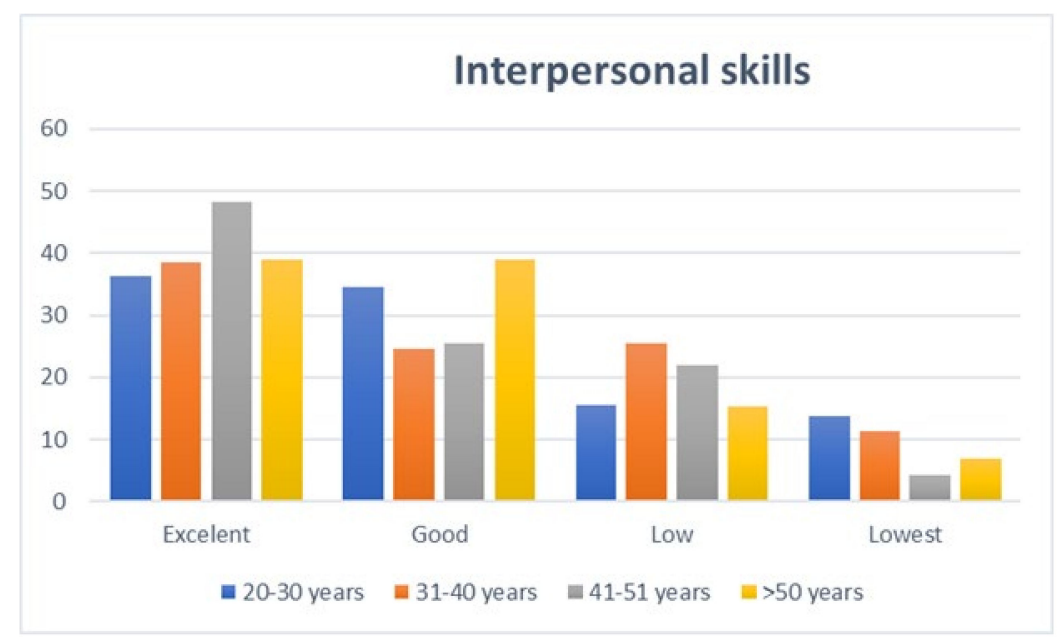

Figure 6. Variation of entrepreneurs' level of interpersonal skills on age category.

Entrepreneurial success is the result of perfect synchronicity between wonderful ideas, good luck, and an environment full of opportunities, combined with the fact that successful entrepreneurs have succeeded in acquiring certain personal skills.

According to Bill J. Bonnstetter [56], these skills are inherent, can be learned and developed especially in the early years of training, and then smoothed along an entrepreneur's career.

\section{Conclusions}

This study was aimed at analyzing the level of development of managerial skills of entrepreneurs who set up and developed a business in Mehedinti County, structured on three levels, thus:

1. Analysis of self-awareness level;

2. analysis of emotional intelligence level;

3. analysis of interpersonal skills development level.

A result of the analysis performed on self-awareness lead to the conclusion that the lack of selfawareness is one of the possible causes of the low density of SMEs/1000 inhabitants in Mehedinți County. The study shows there are issues regarding self-awareness in all age groups, and more than three quarters of the surveyed entrepreneurs need to take action in order to increase it, the categories where this characteristic is most pronounced being that of female entrepreneurs and especially young 
people. These results confirm the progress brought along by early entrepreneurial education, and it is desirable for the curriculum to remain focused on encouraging young people to have a positive attitude towards business, competition, risks, opportunities, and other elements of a functioning market economy.

The high level of emotional intelligence identified in this research shows there is an increasing trend over time, leading to the conclusion that, with age, it increases the managers' ability to understand others and to mobilize the team to achieve high performance and, implicitly, the sustainable development of SMEs.

The level of good and excellent interpersonal skills increases with age as well, proving that working experience is as important as basic and continuous professional training.

Therefore, it can be considered that the sustainable development of SMEs is positively influenced by a high level of emotional intelligence, self-awareness, and interpersonal skills.

The entrepreneur is especially a person with certain attributes and personal qualities having the possibility for a continuous personal development. These characteristics do not represent a guarantee of the entrepreneurial success, but they can create the premises for reaching this goal. They can positively influence the speed of reaction and the quality of decisions at key moments in the business environment [57].

Managerial skills include efficient communication and a good relationship with all people, from all fields. Without these skills, an entrepreneur would be limited only to interacting with certain people who are compatible with his communication style, thus restricting his ability to convey his vision and goals further.

The findings of this study may help the national/regional public policies meant to support SMEs, mostly the start-up programs for which non-reimbursable funds are allocated from national and European public budgets. This support should be better targeted in accordance with the skills and expertise of the applicants. Therefore, an evaluation of managerial skills, as described in the present study, could be included in the evaluation of the application form for financing the starting up of new SMEs, thus contributing to the sustainable development of SMEs.

Therefore, the outcomes of this study can be helpful for the entrepreneurs to understand that the development of their managerial skills is an important factor contributing to the performance and sustainability of the business in terms of Human Resources Management, Marketing, Sales, Production, Logistics.

Last but not least, the results of this study contribute towards enriching the literature on the managerial skills aspects.

Further research directions will be oriented towards extension of this study at national level in Romania, highlighting the differences among NUT 2 regions. After that, another step forward would be the extension of the study in the whole Danube Region, mainly in the post-communist countries. Another possible research direction would be to enhance cooperation among HEIs in the Danube Region, providing higher education in the field of entrepreneurship to develop a common accredited course to improve both managerial skills and access on the labor market for young entrepreneurs.

Author Contributions: Conceptualization, L.P.; methodology, D.A.; formal analysis, V.P.; investigation, A.I.; writing —original draft preparation, L.P. and A.I.; writing—review and editing, L.P. and M.A.; supervision, L.P. and M.A.; project administration, L.P. All authors have read and agreed to the published version of the manuscript.

Funding: This research received no external funding.

Conflicts of Interest: The authors declare no conflict of interest.

\section{References}

1. Krishnan, T.N.; Scullion, H. Talent management and dynamic view of talent in small and medium enterprises. Hum. Resour. Manage. R. 2016. [CrossRef] 
2. Muller, P.; Mattes, A.; Lonkeu, O.K.; Brown, J.; Farrenkopf, J.; Makowska, A.; Robin, N. Annual Report on European SMEs 2017/2018. Special Background Document on the internationalisation of SMEs, SME Performance Review 2017/2018, 2018. Available online: https://ec.europa.eu/ (accessed on 2 December 2019).

3. OECD (Organization for Economic Cooperation and Development) Keynote paper on removing barriers to SME access to international markets. 2007 Geneva: OECD February. Available online: https: //apecmsmemarketplace.com/sites/default/files/doc/10_smewg30_0041.pdf (accessed on 13 January 2020).

4. Muller, P.; Julius, J.; Herr, D.; Koch, L.; Peycheva, V.; McKiernan, S. Annual Report on European SMEs 2016/2017. Focus on self-employment, SME Performance Review 2016/2017, 2017. Available online: https://ec.europa.eu/ (accessed on 28 November 2019).

5. Beaudry, P.; Francois, P. Managerial Skills Acquisition and the Theory of Economic Development. Rev. Econ. Stud. 2010, 77, 90-126. [CrossRef]

6. Psychogios, A.G.; Szamosi, L.T.; Prouska, R.; Brewster, C. A three-fold framework for understanding HRM practices in south-eastern European SMEs. Empl. Relat. 2016, 38, 310-331. [CrossRef]

7. Varum, C.; Rocha, V. Employment and SMEs during crises. Small Bus. Econ. 2013. [CrossRef]

8. Moss Kanter, R. Frontierele managementului; Meteor Press: Bucuresti, Romania, 2007; p. 25. (In Romanian)

9. Stibli, F. Aptitudini necesare managerilor de success. RFT Forter 2009, 1, 191-197. Available online: http://www.revista.forter.ro/2009_1_t/06-inv/02.htm (accessed on 5 March 2018). (In Romanian).

10. Nicolescu, O. Managerii și managementul resurselor umane; Editura Economică: Bucuresti, Romania, $2004 ;$ p. 56. (In Romanian)

11. Mănăilă, I.; Pop, F.; Dimitriu, R.; Măntescu, R.; Petcu, M.; Enache, L.; Hăhăianu, L.; Badea, G.; Neveanu, P. Consilier-Ghid complet pentru managerul HR; Rentrop \& Straton: București, România, 2014; pp. 150-165. (In Romanian)

12. Simionescu, A.; Simionescu, G.; Mironescu, R. Manual de inginerie economica. Management general; Editura Dacia: Cluj-Napoca, Romania, 2002; p. 14. (In Romanian)

13. Katz, R. Skills of an Effective Administrator. Harv. Bus. Rev. 1974, 90-102. Available online: https: //hbr.org/1974/09/skills-of-an-effective-administrator (accessed on 5 March 2018).

14. Whetten, D.; Cameron, K. Developing Management Skills, 8th ed.; Prentice Hall: Upper Saddle River, NJ, USA, 2011.

15. Pfeffer, J. The Human Equation: Building Profits by Putting People First, 1st ed.; Harvard Business Review Press: Boston, MA, USA, 1998; p. 160.

16. Brodbeck, F.; Frese, M.; Akerblom, S.; Audia, G.; Bakacsi, G.; Bendova, H.; Domenico, B.; Bodur, M.; Booth, S.; Gratchev, M.V.; et al. Cultural Variation of Leadership Prototype. J. Occup. Organ. Psychol. 2000, 73, 29. [CrossRef]

17. Roseti, R. Dat sau rezultat? Aptitudini și comportamente antreprenoriale. 2018. Available online: http://revistacariere.ro/leadership/dat-sau-rezultat-aptitudini-si-comportamente-antreprenoriale/ (accessed on 22 June 2019). (In Romanian).

18. Freeman, R.B. Minimum Wages-Again! Int. J. Manpow. 1994, 15, 8-25. [CrossRef]

19. Kalleberg, A.L. The mismatched worker: When people don't fit their jobs. Acad. Manag. Perspect. 2008, 22, 24-40. [CrossRef]

20. Farooq, S. Mismatch between education and occupation: A case study of Pakistani graduates. Pak. Dev. Rev. 2011, 50, 531-552. [CrossRef]

21. Groot, W.; Van Den Brink, H.M. Overeducation in the labor market: A meta-analysis. Econ. Educ. Rev. 2000, 19, 149-158. [CrossRef]

22. Sloane, P.J. Much ado About Nothing? What does the Overeducation Literature Really Tell us. In Overeducation in Europe; Buchel, F., De Grip, A., Mertens, A., Eds.; Edward Elgar Publishing: Cheltenham, UK, 2003; pp. 11-49.

23. McGuinness, S. Overeducation in the labour market. J. Econ. Surv. 2006, 20, 387-418. [CrossRef]

24. Chambers, E.G.; Foulon, M.; Handfield-Jones, H.; Hankin, S.M.; Michaels, E.G. The war for talent. McKinsey Q. 1998, 44-57. Available online: http://www.executivesondemand.net/managementsourcing/images/stories/ artigos_pdf/gestao/The_war_for_talent.pdf (accessed on 4 April 2019).

25. Allen, J.; Van der Velden, R. Educational Mismatches versus Skill Mismatches: Effects on Wages, Job Satisfaction, and On-the-Job Search. Oxf. Econ. Pap. 2001, 53, 434-452. [CrossRef] 
26. Desjardins, R.; Rubenson, K. An Analysis of Skill Mismatch Using Direct Measures of Skills; OECD Education Working Paper No. 63; OECD Publishing: Paris, France, 2011; pp. 46-50.

27. Acemoglu, D.; Autor, D. Skills, Tasks and Technologies: Implications for Employment and Earnings. In Handbook of Labor Economics; Ashenfelter, O., Ed.; Elsevier: Amsterdam, The Netherlands, 2011; Volume 4b, pp. 1043-1171.

28. Cappelli, P.H. Skill gaps, skill shortages, and skill mismatches: Evidence and arguments for the United States. ILR Rev. 2015, 68, 251-290. [CrossRef]

29. Verhaest, D.; Sellami, S.; Van der Velden, R. Differences in horizontal and vertical mismatches across countries and fields of study. Int. Labour Rev. 2017, 156, 1-23. [CrossRef]

30. Allen, J.; de Grip, A. Does skill obsolescence increase the risk of employment loss? Appl. Econ. 2012, 44, 3237-3245. [CrossRef]

31. Piva, M.; Santarelli, E.; Vivarelli, M. The skill bias effect of technological and organisational change: Evidence and policy implications. Res. Policy 2005, 34, 141-157. [CrossRef]

32. Kornelakis, A. Why are your reward strategies not working? The role of shareholder value, country context, and employee voice. Bus. Horis. 2018, 61, 107-113. [CrossRef]

33. OECD. Enhancing the Competitiveness of SMES in the Global Economy: Strategies and Policies; OECD (Organization for Economic Cooperation and Development): Paris, France, 2013; Available online: https://www.oecd.org/ industry/C-MIN-2017--8-EN.pdf (accessed on 11 December 2019).

34. Dan, R.L.; Buglea, A. Politicies and strategies for enhancing the performance of corporate governance. Econ. Ser. 2015, 4, 61-65. (In Romanian)

35. Joshi, S.; Li, Y. What is corporate sustainability and how do firms practice it? A management accounting research perspective. Manag. Account. Res. 2016, 28,1-11. [CrossRef]

36. Kerr, J.; Rouse, P.; Villiers, C.D. Sustainability reporting integrated into management control systems. Account. Rev. 2015, 27, 189-207. [CrossRef]

37. Tooranloo, H.S.; Azadi, M.H.; Sayyahpoor, A. Analyzing factors affecting implementation success of sustainable human resource management (SHRM) using a hybrid approach of FAHP and type-2 fuzzy DEMATEL. J. Clean. Prod. 2017, 162, 1252-1265. [CrossRef]

38. Lloret, A. Modeling corporate sustainability strategy. J. Bus. Res. 2016, 69, 418-425. [CrossRef]

39. Gruianu-Gambla, G. Constientizarea de sine si practica antreprenorului inspirat, 2018. Available online: http: //gabrielagambra.ro/constientizarea-de-sine-si-practica-antreprenorului-inspirat/ (accessed on 27 June 2019). (In Romanian).

40. Goleman, D. Working with Emotional Intelligence; Bantam Books: New York, NY, USA, 1998.

41. Goleman, D.; Boyatzis, R.; McKee, A. Primal Leadership: The Hidden Driver of Great Performance. Harv. Bus. Rev. 2001, 79, 42-51.

42. Goleman, D. Inteligența emoțională, III-a ed.; Editura Curtea Veche: București, Romania, 2008. (In Romanian)

43. Cochran, W.G. Sampling Techniques, 3rd ed.; John Wiley and Sons: New York, NY, USA, 1963.

44. Newey, W.K.; McFadden, D. Large sample estimation and hypothesis testing. In Handbook of Econometrics; Elsevier: Amsterdam, The Netherlands, 1994; Volume 4, pp. 2111-2245.

45. Mureşan, P. Manual de metode matematice în analiza stării de sănătate; Editura Medicală: Bucuresti, Romania, 1989; pp. 25-50. (In Romanian)

46. Badal, S.; Streur, J. 10 Habits of Successful Entrepreneurs. Business Insider. Available online: https: //www.businessinsider.com/10-habits-of-successful-entrepreneurs-2012-9 (accessed on 27 August 2018).

47. Raphekwane, B. Why self-awareness is key to entrepreneurial success, 2015. Available online: https: //www.howwemadeitinafrica.com/why-self-awareness-is-key-to-entrepreneurial-success/49594 (accessed on 30 August 2018).

48. Schneider, K.; Möhring, J.; Proskunina, U. Ego development and innovation orientation of women entrepreneurs in Germany and Ireland. J. Entrep. Educ. 2019, 22. Available online: https://www.abacademies.org/articles/ego-development-and-innovation-orientation-ofwomen-entrepreneurs-in-germany-and-ireland-8127.html (accessed on 10 December 2019).

49. Dâncu, V. Generația înfrântă a României, 2015. Available online: http://revistasinteza.ro/generatia-infrantaa-romaniei/ (accessed on 21 April 2019). (In Romanian).

50. McCarthy, A.M.; Garavan, N.T. Developing self-awareness in the managerial career development process: The value of 360-degree feedback and the MBTI. J. Eur. Ind. Train. 1999, 23, 437-445. [CrossRef] 
51. McKenna, S.D. The darker side of the entrepreneur. Leadership Org. Dev. J. 1996, 17, 41-45. [CrossRef]

52. Carmeli, A. The relationship between emotional intelligence and work attitudes, behavior and outcomes. J. Manag. Psychol. 2003, 18, 788-813. [CrossRef]

53. Gardner, L.; Stough, C. Examining the relationship between leadership and emotional intelligence in senior level managers. Leadership Org. Dev. J. 2002, 23, 68-78. [CrossRef]

54. Fakhreldin, H.; Hattab, H. The effect of emotional intelligence on entrepreneurial behaviour and new venture creation: An Egyptian perspective. IJESB 2019, 37, 399-414. [CrossRef]

55. Ahmetoglu, G.; Leutner, F.; Chamorro-Premuzic, T. EQ-nomics: Understanding the relationship between individual differences in Trait Emotional Intelligence and entrepreneurship. Pers. Individ. Differ. 2011, 51, 1028-1033. [CrossRef]

56. Bonnstetter, B.J. New Research: The Skills That Make an Entrepreneur. Harvard Business Review. Available online: https://hbr.org/2012/12/new-research-the-skills-that-m?referral=03758\&cm_vc=rr_item_page.top_ right (accessed on 10 September 2019).

57. Ghenea, M. Antreprenoriat: Drumul de la idei către oportunități și succes în afaceri; Editura Universul Juridic: Bucuresti, Romania, 2011. (In Romanian)

(C) 2020 by the authors. Licensee MDPI, Basel, Switzerland. This article is an open access article distributed under the terms and conditions of the Creative Commons Attribution (CC BY) license (http://creativecommons.org/licenses/by/4.0/). 